\title{
Specific Detection of Subgroups I and II of Cucumber Mosaic Virus RNA with Digoxigenin-Labeled Synthetic Oligo-Deoxyribonucleotide Probes*
}

\author{
Yoichi TAKAnAmi**, Takayuki UChIBA**, Tomohiro SHIGEMI**, \\ Kenji KIKUHARA** and Minoru TAKeShiTA**
}

\begin{abstract}
Key words : cucumber mosaic virus, oligo-deoxyribonucleotide probe, digoxigenin-labeled, RNA detection, subgroup-specific detection.
\end{abstract}

Cucumber mosaic cucumovirus (CMV) has a genome consisting of three plus-sense, single-stranded RNA molecules, designated RNA1, RNA2 and RNA3 in decreasing order of molecular weight, and is divided into subgroups I and II based on serological properties and differences in nucleotide sequence ${ }^{10)}$.

Many efforts have been made to prevent the enormous damage to agricultural crop production caused by CMV. For example, preinoculation of plants with attenuated CMV was successfully adopted to escape reinfection with more virulent strains ${ }^{17}$. A number of studies also describe the establishment of CMV resistance in transgenic plants which express the gene of CMV coat protein, non-structural protein or satellite $\mathrm{RNA}^{2}$. The principle of these strategies is based on "cross-protection" of plant viruses. We are now investigating the molecular basis of the phenomenon using various CMV strains. In the course of this study, we need to develop methods that can discriminate the syntheses of subgroups I and II of CMV RNAs in doubly infected cells or leaf tissues.

The identity in nucleotide sequences among RNAs of CMV strains in the same subgroup is over 95\%, whereas that between subgroup I and subgroup II is less than $80 \%{ }^{10)}$. Because the $3^{\prime}$-noncoding regions of RNAs 1,2 and 3 of CMV have highly conserved nucleotide sequences, a DNA or RNA probe complementary to the regions was able to detect all the genomic RNAs at almost the same efficiency ${ }^{3)}$. A comparison of the nucleotide sequences of the $3^{\prime}$-noncoding regions between subgroups I and II revealed a stretch of sequence which was specific for each subgroup. This paper describes the reliability of digoxigenin (DIG)-labeled, synthetic oligodeoxyribonucleotide probes complementary to the regions for the subgroup-specific detection of $\mathrm{CMV}$ RNAs by dot-blot or northern blot analyses.

CMV strains used in this experiment were as follows : subgroup I-CMV-Y ${ }^{18)}$, CMV-O ${ }^{5)}$, both of which belong to subgroup $I^{4,6,7,9)}$, and $\mathrm{CMV}$-m1 that was shown to be of subgroup I by serological test ${ }^{16)}$; subgroup II-CMV-m2 and CMV-GT, which were shown to be of subgroup II based on the nucleotide sequences, serological test or symptom observation ${ }^{16}$. Viruses were propagated in tobacco plants (Nicotiana tabacum L. cv. Xanthi-nc) and purified as described previously ${ }^{14)}$.

Oligo-deoxyribonucleotides were synthesized by an automated DNA synthesizer. The $5^{\prime}$ ends of the DNA were chemically labeled with DIG according to the instructions of the manufacturer (Boehringer Mannheim). Four probes, two for each subgroup, were prepared based essentially on the sequences of the $3^{\prime}$-noncoding regions of CMV-Y RNA3 ${ }^{6,7,9)}$ and CMV-m2 RNA3 ${ }^{16)}$ as shown in Fig. 1. Probes Y-1 and Y-2 were designed to detect subgroup I CMV. Probe Y-1 was complementary to the sequence of CMV-Y RNA3 having 40 deoxyribonucleotides with a GC content of $52.5 \%$. Probe Y-2 was designed as a degenerate primer of 44 deoxyribonucleotides with a GC content of $47.7-52.3 \%$ containing $\mathrm{G}$ or $\mathrm{A}$ at the positions 8 and 30 from the $5^{\prime}$ end, because some variations in the nucleotide sequences at several positions were found among the species of RNA segments and virus isolates belonging to subgroup I. Probes m2-1 and m2-2 for subgroup II are 40 and 45 deoxyribonucleotides long with GC contents of 42.5 and $46.7 \%$, respectively. No nucleotide variations in the regions covered by probes $\mathrm{m} 2-1$ and $\mathrm{m} 2-2$ were found among RNA3s of subgroup II isolates, CMV-m2, CMVQ, CMV-Kin and CMV-Trk, when compared using the DDBJ/GenBank/EMBL DNA data base.

Hybridization and detection of RNA on nylon membranes (Hybond- $\mathrm{N}^{+}$, Amersham) were carried out as follows. After being baked at $80^{\circ} \mathrm{C}$ for $2 \mathrm{hr}$, the blotted membranes were prehybridized in a hybridization buffer containing $5 \times \mathrm{SSC}, 50 \%$ formamide, $50 \mathrm{mM}$ phosphate buffer, $\mathrm{pH} 7.0$, 2\% blocking reagent (Boehringer Mannheim), $0.1 \% N$-lauroylsarcosine, $1 \mathrm{mg} / \mathrm{ml}$ yeast total RNA at $45^{\circ} \mathrm{C}$ for $3 \mathrm{hr}$. The buffer was replaced with a fresh one containing $20 \mathrm{ng} / \mathrm{ml}$ of the DIG-labeled probe.

* This study was supported by Grants-in-Aid for Scientific Research (A) 08406004 from The Ministry of Education, Science, Sports and Culture of Japan.

** Graduate School of Bioresource and Bioenvironmental Sciences, Kyushu University, Higashi-ku, Fukuoka 812-8581, Japan 九州大学大学院生物資源環境科学研究科 


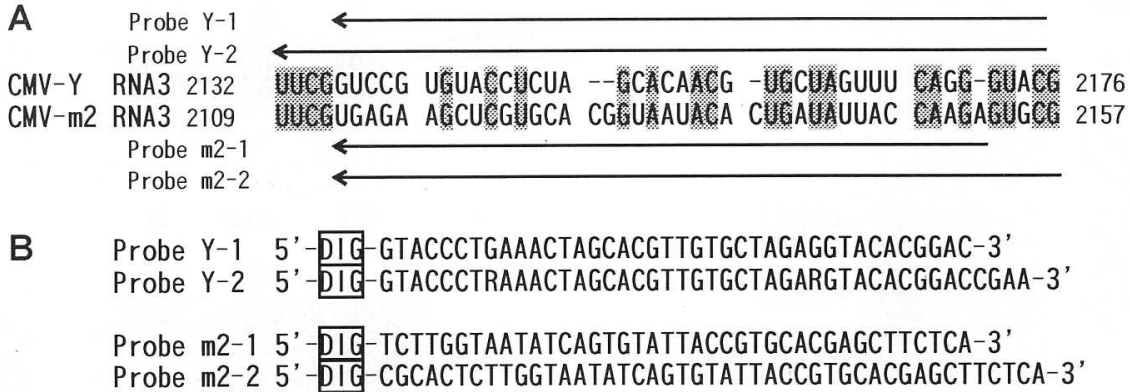

Fig. 1. DIG-labeled synthetic oligo-deoxyribonucleotide probes for subgroup-specific detection of CMV RNAs. (A) Comparison of nucleotide sequences near the $3^{\prime}$ ends of RNA3s of CMV-Y (subgroup I) and CMV-m2 (subgroup II) where considerable nucleotide changes were found between the two isolates. Identical nucleotides are shaded. Lines with arrows indicate the regions complementary to the respective probes. (B) Structure and nucleotide sequences of the probes. The $5^{\prime}$ ends of the probes were chemically labeled with DIG. Nucleotides R at positions 8 and 30 of probe $\mathrm{Y}-2$ indicate $\mathrm{A}$ or $\mathrm{G}$.

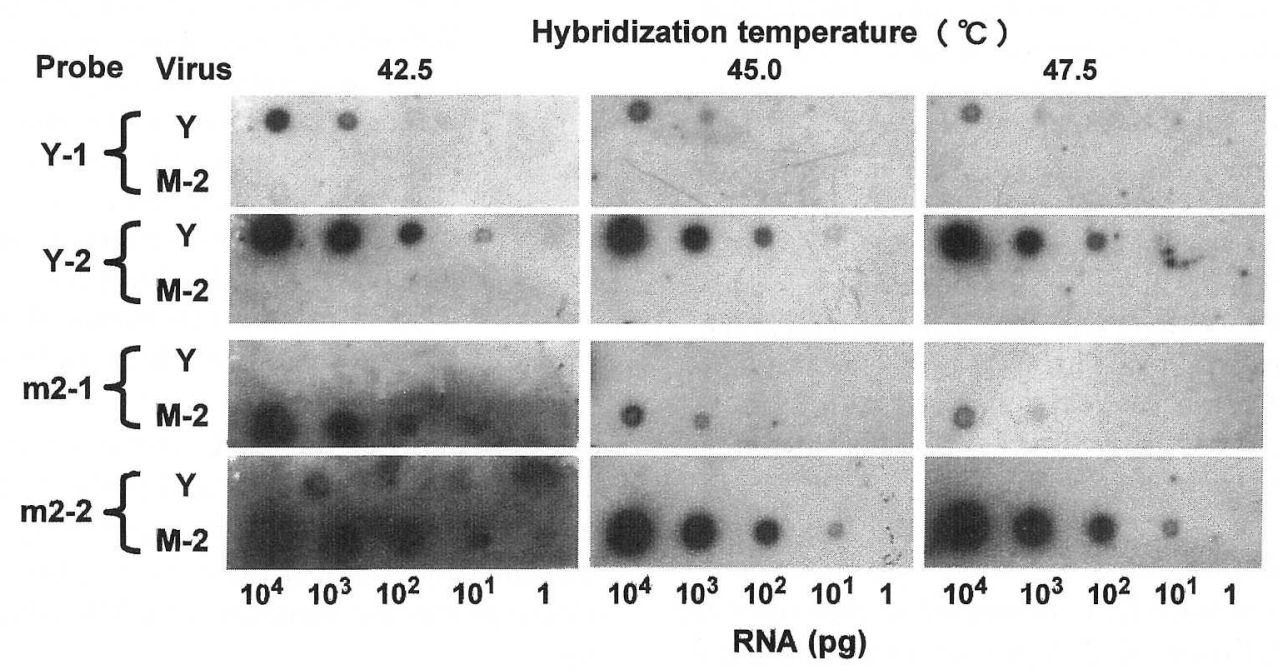

Fig. 2. Effect of hybridization temperature on the subgroup-specific detection of CMV RNA by dot-blot hybridization using DIG-labeled oligo-deoxyribonucleotide probes. Hybridization was done at $42.5,45.0$ or $47.5^{\circ} \mathrm{C}$. Purified virions of CMV-Y and CMV-m2 were dissociated with SDS and dot-blotted onto nylon membranes at various amounts of RNA as indicated at the bottom. The amount of RNA was calculated assuming that the RNA content of CMV was $18.5 \%$.

The membranes were incubated at $42.5,45.0$ or $47.5^{\circ} \mathrm{C}$ for $16 \mathrm{hr}$, then washed in $1 \times \mathrm{SSC}$ containing $0.1 \% \mathrm{SDS}$ for $20 \mathrm{~min}$ followed by washing twice in $0.2 \times \mathrm{SSC}$ containing $0.1 \%$ SDS for $20 \mathrm{~min}$ at the fixed temperatures plus $5^{\circ} \mathrm{C}$. After washing in maleic buffer $(0.1 \mathrm{M}$ maleic acid, pH 7.5, 0.15 M NaCl) containing $0.3 \%(\mathrm{v} / \mathrm{v})$ Tween 20 for $5 \mathrm{~min}$ at room temperature, the membranes were incubated with the maleic buffer containing $1 / 10$ volumes of blocking solution (10\% blocking reagent) for $30 \mathrm{~min}$ followed by incubation in the same buffer containing $75 \mathrm{mU} / \mathrm{ml}$ of sheep anti-DIG Fab fragments conjugated with alkaline phosphatase (Boehringer Mannheim) for $30 \mathrm{~min}$. The membranes were then washed twice in the maleic buffer containing $0.3 \%(\mathrm{v} / \mathrm{v})$ Tween 20 for $15 \mathrm{~min}$. After equilibrating in $0.1 \mathrm{M}$ Tris$\mathrm{HCl}, \mathrm{pH} 9.5,0.1 \mathrm{M} \mathrm{NaCl}, 50 \mathrm{mM} \mathrm{MgCl}_{2}$ for $3 \mathrm{~min}$, the membranes were incubated in the same buffer containing $1 / 2000$ volumes of a chemiluminescence reagent, CSPD (Boehringer Mannheim), in plastic hybridization bags at $37^{\circ} \mathrm{C}$ for $15 \mathrm{~min}$. The solution was squeezed out of the bags, which were then sealed and exposed to $\mathrm{X}$-ray films for an appropriate time (1 hr to overnight).

To determine the optimum temperature for the hybridization reaction between target RNAs and the probes, dot-blot hybridization was carried out at different temperatures using the four different probes and CMV-Y and CMV-m2 RNAs. Purified virions ( $1 \mathrm{mg}$ / $\mathrm{ml}$ ) were dissociated with a final volume of $1 \%$ SDS and serially diluted with $10 \mathrm{mM}$ Tris- $\mathrm{HCl}, \mathrm{pH} 8.0,1 \mathrm{mM}$ EDTA, then $1 \mu 1$ of the solution was spotted onto the nylon membrane (Fig. 2). Probes Y-1 and Y-2 produced clear signals for CMV-Y RNA, but did not for CMV-m2 RNA irrespective of temperature, although probe Y-2 showed approximately 100 times higher sensitivity than probe Y-1. Probe Y-2 could detect less than $10 \mathrm{pg}$ of CMV-Y RNA. Probe m2-1 could specifically detect CMV-m2 RNA although the sensitivity was lower, especially at higher temperatures. In contrast, 


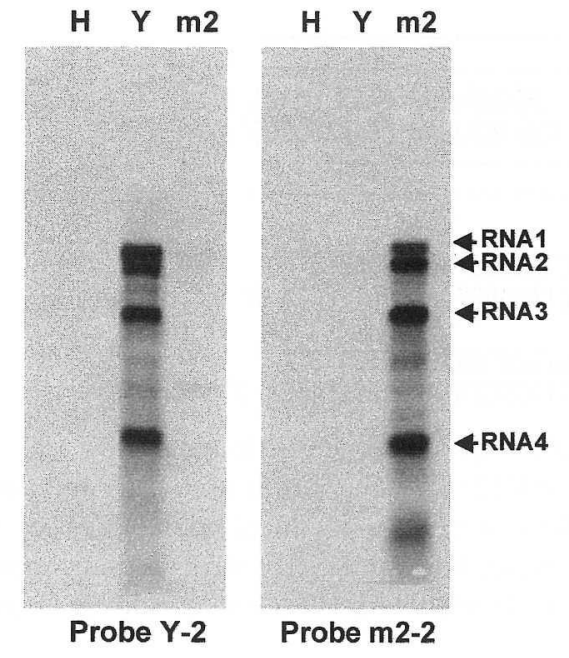

Fig. 3. Subgroup-specific detection of CMV RNAs by northern blot hybridization using DIG-labeled oligo-deoxyribonucleotide probes. Total RNA extracted from the tobacco leaves one week after inoculation with CMV-Y or CMV-m2 was electrophoresed in 1\% agarose gel, then transferred to nylon membrane. The amount of total RNA per each lane corresponded to that in 7.5 $\mathrm{mg}$ of the fresh leaves. Hybridization was done at $45.0^{\circ} \mathrm{C}$. Viral RNAs were detected with probe Y-2 or m2-2. Y and $\mathrm{m} 2$ indicate the total RNAs from the tobacco leaves infected with CMV-Y and $\mathrm{CMV}-\mathrm{m} 2$, respectively. $\mathrm{H}$ indicates the healthy control.

probe $\mathrm{m} 2-2$, which is four bases longer than probe $\mathrm{m} 2-1$, exhibited higher sensitivity comparable to that obtained with probe Y-2. Probe m2-2, however, produced higher backgrounds and nonspecific signals at $42.5^{\circ} \mathrm{C}$. Based on these results, we decided to use routinely probes $\mathrm{Y}-2$ and $\mathrm{m} 2-2$ at $45.0-47.5^{\circ} \mathrm{C}$.

Total RNAs of tobacco leaves infected with CMV-Y or CMV-m2 were obtained as described previously ${ }^{15)}$. The total RNA was electrophoresed in a 1.5\% agarose gel under denaturing conditions with $0.66 \mathrm{M}$ formaldehyde, then transferred to a nylon membrane according to standard procedures ${ }^{13)}$. Viral RNAs were detected with probe Y-2 or m2-2 as described previously when the hybridization was done at $45.0^{\circ} \mathrm{C}$. As shown in Fig. 3, CMV RNAs 1, 2, 3 and 4 were clearly detected in the total RNAs, and each probe hybridized to only CMV RNAs of the corresponding subgroup. The total RNAs from healthy control leaves gave no signals.

To know whether the probes can specifically detect viral RNAs in crude leaf saps, tobacco leaves infected with CMV-Y, CMV-O, CMV-m1, CMV-GT or CMV-m2 were homogenized in five volumes $(\mathrm{v} / \mathrm{w})$ of $100 \mathrm{mM}$ Tris- $\mathrm{HCl}, \mathrm{pH}$ 8.0, 10 mM EDTA, 100 mM LiCl, 1\% SDS and centrifuged at 10,000 rpm for $3 \mathrm{~min}$. Then $1 \mu 1$ of the supernatant was directly spotted onto the nylon membrane. Viral RNAs hybridized with probe Y-2 or m2-2 at 42.5 or $47.5^{\circ} \mathrm{C}$. As shown in Fig. 4, both probes gave specific positive signals without any cross reactions at
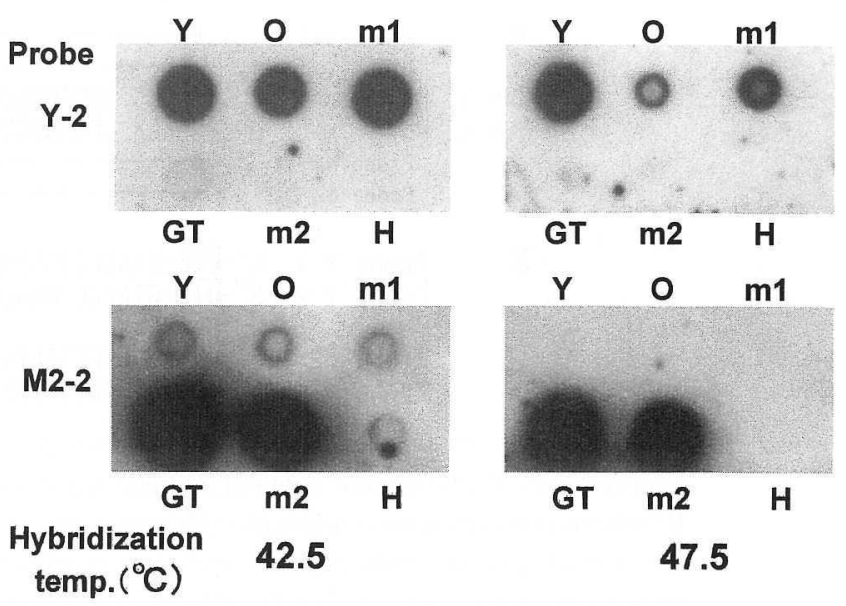

Fig. 4. Subgroup-specific detection of CMV RNAs in crude saps of tobacco leaves infected with CMV strains by dot-blot hybridization using DIG-labeled oligo-deoxyribonucleotide probes. Crude saps were prepared by homogenizing the leaves in buffer containing SDS and centrifuging at low speed as described in the text. Hybridization was done at 42.5 or $47.5^{\circ} \mathrm{C}$. Tobacco plants were infected with CMV-Y (Y), $-\mathrm{O}(\mathrm{O})$, or $-\mathrm{m} 1(\mathrm{~m} 1)$ of subgroup I and CMV-GT (GT) or -m2 (m2) of subgroup II. H indicates the crude extracts from the mock-inoculated plants.

$47.5^{\circ} \mathrm{C}$. In contrast, at $42.5^{\circ} \mathrm{C}$, probe $\mathrm{m} 2-2$ produced rather strong nonspecific signals and probe Y-2 produced very faint signals for CMV-GT, suggesting that the lower hybridization temperature was also unsuitable for subgroup-specific detection of CMV RNA in crude leaf saps.

Several papers have reported the use of DIG-labeled cDNA or in vitro transcribed cRNA probes for the detection of viral RNAs in plants ${ }^{1,8,11,12)}$. Our results showed that dot-blot and northern blot hybridization using DIG-labeled synthetic oligo-deoxyribonucleotide probes were subgroup specific in detecting RNAs of CMV. We found no cross-reactions between viral RNAs of subgroup I and II and no nonspecific reactions against healthy control samples under suitable conditions for hybridization and exposure to X-ray film. The lower hybridization temperature and prolonged exposure times somewhat decreased the specificity of probe m2-2. Colorimetric detection using nitroblue tetrazolium and 5-bromo-4-chloro-3-indolyl phosphate also gave signals with somewhat lower sensitivity compared to the chemiluminescent one, although the former was more rapid and simple (data not shown).

The length of the probes greatly affected the sensitivity for the detection of CMV RNA. In fact, the extensions of probes Y-1 and $\mathrm{m} 2$ with four and five deoxyribonucleotides, respectively, increased the sensitivity approximately 100-fold. Our results showed that short probes of only 44 to 45 nucleotides could detect as little as $10 \mathrm{pg}$ CMV RNA by dot-blot hybridization. This level of sensitivity was comparable with that obtained using 
cloned cDNA biotin or ${ }^{32} \mathrm{P}$-labeled probes for the detection of papaya mosaic potexvirus $\mathrm{RNA}^{11)}$.

The long shelf life of the probes and the simplicity, high sensitivity and versatility of our method will greatly facilitate the subgroup-specific detection of CMV RNAs especially in plants or cells that are doublyinfected with CMV isolates of different subgroups.

We thank Dr. Hanada, Kyushu National Agricultural Experiment Station, Kumamoto, Japan for the supply of CMV-GT.

\section{Literature cited}

1. Dietzgen, R.G., Xu, Z. and Teycheney, P.-Y. (1994). Digoxigenin-labeled cRNA probes for the detection of two potyviruses infecting peanut (Arachis hypogaea). Plant Dis. 78: 708-711.

2. Fitchen, J.H. and Beachy, R.N. (1993). Genetically engineered protection against viruses in transgenic plants. Annu. Rev. Microbiol. 47 : 739-763.

3. Gal-On, A., Kaplan, I., Roossinck, M.J. and Palukaitis, P. (1994). The kinetics of infection of zucchini squash by cucumber mosaic virus indicate a function for RNA 1 in virus movement. Virology 205 : 280-289.

4. Hayakawa, T., Mizukami, M., Nakajima, M. and Suzuki, M. (1989). Complete nucleotide sequence of RNA3 from cucumber mosaic virus (CMV) strain O : Comparative study of nucleotide sequences and amino acid sequences among CMV strains O, Q, D and Y. J. Gen. Virol. $70:$ 499-504.

5. Hidaka, Z. and Tomaru, K. (1960). Strains of cucumber mosaic virus isolated from tobacco plants. I. Ordinary strain. Bull. Hatano Tob. Exp. Stn. 46 : 125-134.

6. Kataoka, J., Masuta, C. and Takanami, Y. (1990). Complete nucleotide sequence of RNA2 of cucumber mosaic virus Y strain. Ann. Phytopathol. Soc. Jpn. 56: 495-500.

7. Kataoka, J., Masuta, C. and Takanami, Y. (1990). Complete nucleotide sequence of RNA1 of cucumber mosaic virus $\mathrm{Y}$ strain and evolutionary relationships among genome RNAs of the virus strains. Ann. Phytopathol. Soc. Jpn. 56 : 501-507.

8. Mas, P., Sanches-Navarro, J.A., Sanches-Pina, M.A. and Pallas, V. (1993). Chemiluminescent and colorigenic detection of cherry leaf roll virus with digoxigeninlabeled RNA probes. J. Virol. Methods 45 : 93-102.

9. Nitta, N., Masuta, C., Kuwata, S. and Takanami, Y. (1988). Comparative studies on the nucleotide sequence of cucumber mosaic virus RNA3 between Y strain and Q strain. Ann. Phytopathol. Soc. Jpn. 54: 516-522.

10. Palukaitis, P., Roossinck, M.J., Dietzgen, R.G. and Francki, R.I.B. (1992). Cucumber mosaic virus. Adv. Virus Res. 41 : 281-348.

11. Roy, B.P., AbouHaidar, M.G., Sit, T.L. and Alexander, A. (1988). Construction and use of cloned cDNA biotin and ${ }^{32} \mathrm{P}$-labeled probes for the detection of papaya mosaic potexvirus RNA in plants. Phytopathology 78 : 1425-1429.

12. Saito, M., Kiguchi, T. and Tamada, T. (1997). Nonradioactive, digoxigenin-labeled DNA probes for the detection of five RNA species present in beet necrotic yellow vein virus. Bull. Res. Inst. Bioresour. Okayama Univ. 5 : 79-96.

13. Sambrook, J., Fritsch, E.F. and Maniatis, T. (1989). Molecular Cloning : A Laboratory Manual, 2nd ed., Cold Spring Harbor Laboratory, New York.

14. Takanami, Y. (1981). A striking change in symptoms on cucumber mosaic virus-infected tobacco plants induced by a satellite RNA. Virology $109: 120-126$.

15. Takanami, Y., Imaizumi, S. and Kubo, S. (1977). Synthesis of single- and double-stranded cucumber mosaic virus RNAs in tobacco mesophyll protoplasts. Virology $80: 376-389$.

16. Takanami, Y., Kikuhara, K. and Takeshita, M. (1998). Two isolates of cucumber mosaic cucumovirus expressing mild mosaic symptoms on tobacco plants. J. Fac. Agric. Kyushu Univ. 43 : 53-58.

17. Tien, P., Zhang, X., Qiu, B., Qin, B. and Wu, G. (1987). Satellite RNA for the control of plant disease caused by cucumber mosaic virus. Ann. appl. Biol. 111 : 143-152.

18. Tomaru, K. and Hidaka, Z. (1960). Strains of cucumber mosaic virus isolated from tobacco plants. III. A yellow strain. Bull. Hatano Tob. Exp. Stn. 46 : 143-149.

\section{和 文 摘 要}

高浪洋一・内場隆行・重見知宏・菊原賢次 - 竹下 稔: DIG 標 識合成オリゴデオキシリボヌクレオチドプローブを用いたキュ ウリモザイクウイルス RNA のサブグループ特異的検出

キュウリモザイクウイルス (CMV) は血清学的性質ならびに 塩基配列の違いから subgroup I と II に大別されている。異なる subgroup に属するCMV 分離株に混合感染した感染植物組織 内のそれぞれのウイルス RNA を特異的に検出することを目的 として，ジゴキシゲニン（DIG）標識合成プローブを用いた hybridizationを試みた。CMVの 3 種のゲノム RNA はほぼ共 通した塩基配列の $3^{\prime}$ 末端非翻訳領域 ( $3^{\prime} \mathrm{NCR}$ )を有することか ら，1本のプローブですべての RNA の検出が可能であること が知られているが，3'NCR の一部に subgroup 間で塩基配列が 大きく異なる領域が存在する。その領域に相補的な DIG 標識合 成オリゴデオキシリボヌクレオチドをそれぞれプローブとして 準備し, nylon membrane 上で dot-blot および northern blot hybridizationを行った。alkaline phosphatase 標識 DIG 抗体 および化学発光基質を用いた場合, dot-blot で $10 \mathrm{pg}$ の CMV RNA が検出可能であった。また, northern blot hybridization においては各 subgroup の RNA1〜4のすべてが特異的に検出 された。さらに, 感染粗汁液を直接ブロットした場合でも subgroup 特異的な CMV RNA の検出が可能であった。本法は, 標 識プローブの長期安定性, 操作の簡便性ならびに放射能を用い る方法に比肩し得る十分な検出感度などの利点を有し, CMV RNA の subgroup 特異的検出に有用と思われる。

(Received July 6, 1998 ; Accepted October 8, 1998) 